\title{
In vitro study on the cell adhesion ability of immobilized lactobacilli on natural supports
}

Article

Accepted Version

Sidira, M., Kourkoutas, Y., Kanellaki, M. and

Charalampopoulos, D. (2015) In vitro study on the cell adhesion ability of immobilized lactobacilli on natural supports. Food Research International, 76 (3). pp. 532-539. ISSN 09639969 doi: https://doi.org/10.1016/j.foodres.2015.07.036 Available at https://centaur.reading.ac.uk/41769/

It is advisable to refer to the publisher's version if you intend to cite from the work. See Guidance on citing.

Published version at: http://dx.doi.org/10.1016/j.foodres.2015.07.036

To link to this article DOI: http://dx.doi.org/10.1016/j.foodres.2015.07.036

Publisher: Elsevier

All outputs in CentAUR are protected by Intellectual Property Rights law, including copyright law. Copyright and IPR is retained by the creators or other copyright holders. Terms and conditions for use of this material are defined in the End User Agreement.

www.reading.ac.uk/centaur 
Central Archive at the University of Reading

Reading's research outputs online 
1 In vitro study on the cell adhesion ability of immobilized lactobacilli

2 on natural supports

5 Marianthi Sidira ${ }^{a, b}$, Yiannis Kourkoutas ${ }^{b}$, Maria Kanellaki ${ }^{a}$, and Dimitris

6 Charalampopoulos ${ }^{\mathrm{c}^{*}}$

7 a. Food Biotechnology Group, Section of Analytical Environmental and Applied 8 Chemistry, Department of Chemistry, University of Patras, GR-26500 Patras, Greece.

9 b. Applied Microbiology and Molecular Biotechnology Research Group, Department 10 of Molecular Biology \& Genetics, Democritus University of Thrace, Alexandroupolis, 1168100, Greece.

12 c. Department of Food and Nutritional Sciences, The University of Reading, PO Box 13 226, Whiteknights, Reading, RG6 6AP, UK

14

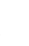

Corresponding author: Charalampopoulos Dimitris

Mailing address: Department of Food and Nutritional Sciences, The University of Reading, PO Box 226, Whiteknights, Reading, RG6 6AP, UK

\section{E-mail: d.charalampopoulos@reading.ac.uk}




\section{Abstract}

The aim of the present study was to investigate the effect of probiotic immobilization onto wheat grains, both wet and freeze dried, on the adhesion properties of the probiotic cells and make comparisons with wet and freeze dried free cells. Lactobacillus casei ATCC 393 and Lactobacillus plantarum NCIMB 8826 were used as model probiotic strains. The results showed satisfactory adhesion ability of free cells to a monolayer of Caco- 2 cells (>1000 CFU/100 Caco-2 cells for wet cells). Cell immobilization resulted in a significant decrease in adhesion, for both wet and freeze dried formulations, most likely because immobilized cells did not have direct access to the Caco-2 cells, but it still remained in adequate levels (>100 CFU/100 Caco-2 cells for wet cells). No clear correlation could be observed between cell adhesion and the hydrophobicity of the bacterial cells, measured by the hexadecane adhesion assay. Most notably, immobilization enhanced the monolayer integrity of Caco-2 cells, demonstrated by a more than 2-fold increase in transepithelial electrical resistance (TEER) compared to free cells. SEM micrographs ascertained the adhesion of both immobilized and free cells to the brush border microvilli. Finally, the impact of the food matrix on the adhesion properties of probiotic bacteria and on the design of novel functional products is discussed.

Keywords: Probiotics, Lactic acid bacteria, Adhesion, Caco-2 cells 


\section{Introduction}

Nowadays, there is a growing interest in developing foods containing probiotic microorganisms, such as bifidobacteria and lactic acid bacteria (LAB). Such functional cultures may offer organoleptic, technological and nutritional advantages, but more importantly confer a health benefit to the host. Indeed, administration of probiotics has been linked to the prevention, and in some cases reduction or treatment, of various diseases, including viral or bacterial diarrhea, gastroenteritis, irritable bowel syndrome, inflammatory bowel disease (Crohn's disease and ulcerative colitis), depressed immune function, lactose intolerance, infant allergies, Helicobacter pylori infections, antibiotic-associated diarrhea in children and others (Deshpandea, Rao, \& Patolea, 2011; Hempel et al., 2012; Ritchie, \& Romanuk, 2012).

In order to deliver the health benefits, probiotic products need to contain an adequate amount of live cells (at least $10^{6}-10^{7} \mathrm{CFU} / \mathrm{g}$ of product) (Boylston, Vinderola, Ghoddusi, \& Reinheimer, 2004), the cells should be able to survive the acidic conditions of the upper gastrointestinal (GI) tract, adhere to mucosal-epithelial surfaces and colonize the colon, exhibit antimicrobial activity against pathogenic bacteria and bile salt hydrolase activity (Boylston et al., 2004; Kechagia et al., 2013; Nagpal et al, 2012). Adhesion of probiotics to the intestinal mucosa is an important prerequisite for transient colonization within the GI, and it is an area that attracts considerable amount of research. To evaluate the adhesion abilities, in vitro methods have been applied using mainly the Caco-2 cell line (Tuomola \& Salminen, 1998; Hilgendorf et al., 2000). Lactobacillus casei, L. plantarum and L. rhamnosus are commonly used probiotic bacteria and have been shown to exert medium to strong binding towards Caco-2 cells (Segers \& Lebeer, 2014; Douillard et al., 2013; Elo, Saxelin, \& Salminen, 1991; Duary, Rajput, Batish, \& Grover, 2011). 
A variety of methods have been applied to determine the adhesive properties

of bacterial cells. The microbial adhesion to hydrocarbons (MATH) method measures various forces contributing to the adhesion of bacterial cells to hydrophobic solvents, including van der Waals, electrostatic and short-range interactions, as adhesion to hydrocarbons reflects a number of physico-chemical interactions involved in adhesion and not exclusively hydrophobicity (van der Mei, van der Belt-Gritter, Pouwels, Martinez, \& Busscher, 2003; Oliveira, Azeredo, Teixeira, \& Fonseca, 2001). It must be noted that there is very little information on how the formulation, for example the food matrix, affects the physicochemical properties of the cells, and hence their hydrophobicity and adhesion ability.

The transepithelial electrical resistance (TEER) assay determines the attainment of permeability in vitro and also includes the measurement of electrical physical resistance (Klingberg, Pedersen, Cencic, \& Budde, 2005). Using the TEER assay as a measure of the integrity of the tight junctions between intestinal epithelial cells, studies have shown that some bacteria can enhance the intestinal barrier function (Anderson, Cookson, McNabb, Kelly, \& Roy, 2010b). Probiotic bacteria, such as L. plantarum WCFS1 or L. plantarum MB452, Lactobacillus rhamnosus GG, Bifidobacterium infantis, Lactobacillus casei subsp. rhamnosus Lcr35, have been used to enhance the intestinal barrier, which is compromised in a number of intestinal disorders, such as inflammatory bowel diseases, irritable bowel syndrome and some types of food-borne infections (Karczewski et al., 2010; Anderson et al., 2010a; Fang et al., 2010).

The incorporation of probiotic microorganisms within a food matrix presents significant challenges, not only because of the interactions of the cells with a variety of chemical components, but also because of the unfavourable conditions often 
employed during food processing and storage which might lead to high losses in viability. This is in particular evident when probiotics are incorporated into complex food matrices, such as cheese and meat products (Sidira, Karapetsas, Galanis, Kanellaki, \& Kourkoutas, 2014a). To overcome these adversities, immobilization of probiotic cells onto a solid support, prior to their inclusion into the targeted food matrix, can be used to protect the cells and maintain their viability, activity and functionality during processing and storage. To this end, several studies have demonstrated the successful immobilization of probiotic bacteria onto various natural food-grade material supports, such as starch (Mattila-Sandholm et al., 2002), fruit pieces (Kourkoutas et al., 2006; Kourkoutas, Xolias, Kallis, Bezirtzoglou, \& Kanellaki, 2005), casein (Dimitrellou, Kourkoutas, Koutinas, \& Kanellaki, 2009) and wheat grains (Bosnea et al., 2009), and their application into food products, such as sausages (Sidira et al., 2014a) and cheese (Kourkoutas et al., 2006). However, there is limited knowledge, on how immobilization affects the functional properties of the probiotic cells, and in particular their ability to adhere to epithelial cells and their action as an intestinal barrier.

The probiotic properties of free and immobilized L. casei ATCC 393 were previously assessed by documenting the maintenance of cell viability after transit through the GI tract, adhesion at the large intestine and regulation of the intestinal microbiota in rats (Saxami et al., 2012, Sidira et al., 2010). Although, it was suggested that adhesion to the GI tract was transient, indicating the need for daily consumption of probiotic products containing the specific strain, no information about the effect of cell immobilization on adhesion properties were available. Similarly, in vivo experiments showed that L. plantarum enhanced the intestinal barrier and induced changes in the epithelial tight junctions (Karczewski et al., 2010). 
123 probiotic immobilization onto wheat grains (wet and freeze dried) on the adhesion 124 properties of lactobacilli using the model probiotic strains L. casei ATCC 393 and $L$. 125 plantarum NCIMB 8826 in comparison to free wet and freeze dried cells. $L$. 126 plantarum NCIMB 8826 was selected due to the strong binding characteristics 127 (Izquierdo et al., 2009; Kinoshita et al., 2008), resistance to acidic conditions 128 (Charalampopoulos, Pandiella, \& Webb, 2002), survival during refrigerated storage 129 (Charalampopoulos \& Pandiella, 2010) and in fruit juices (Nualkaekul \& 130 Charalampopoulos, 2011), while L. casei ATCC 393 due to its good survival in the 131 GI tract (Saxami et al., 2012; Sidira et al., 2010) and excellent technological properties (Bosnea et al., 2009; Kourkoutas et al., 2006, 2005; Sidira et al., 2014a).

\section{Materials and methods}

\subsection{Strain maintenance and growth}

L. casei ATCC 393 (DSMZ, Germany) and L. plantarum NCIMB 8826 (National Collection of Industrial and Marine Bacteria, UK) were stored at $-20{ }^{\circ} \mathrm{C}$ in 2 $\mathrm{ml}$ cryovials containing $20 \%(\mathrm{v} / \mathrm{v})$ glycerol. The cells were initially propagated at 37 then cultivated at $37{ }^{\circ} \mathrm{C}$ in $500 \mathrm{ml}$ flasks for $72 \mathrm{~h}$ containing $200 \mathrm{ml}$ of the same

141 culture medium. The free cells were collected by centrifugation at $3200 \mathrm{~g}$ and $4{ }^{\circ} \mathrm{C}$ for 14215 min.

\subsection{Cell immobilization}

Wheat grains were used as immobilization support. Prior to use, they were 145 boiled and sterilized at $130{ }^{\circ} \mathrm{C}$ for $15 \mathrm{~min}$. Cell immobilization was carried out as 146 described previously (Bosnea et al., 2009). In brief, $50 \mathrm{~g}$ of immobilization support 
and $\sim 1 \mathrm{~g}$ (wet weight) of L. casei ATCC 393 or L. plantarum NCIMB 8826 cells were added into $1 \mathrm{~L}$ flasks containing $500 \mathrm{ml}$ of MRS broth. The culture was incubated at $37{ }^{\circ} \mathrm{C}$ without agitation for $48 \mathrm{~h}$. The immobilized cells were collected by washing twice with sterilized 1/4 Ringer's solution (Sigma-Aldrich, UK) for removal of nonimmobilized free cells. The immobilized cells were either used directly or subjected to freeze-drying.

\subsection{Freeze-drying of free and immobilized cells}

Free and immobilized cells were freeze-dried as described previously (Siaterlis, Deepika, \& Charalampopoulos, 2009). Briefly, the immobilized cells were washed three times with 1/4 Ringer's solution and transferred into $250 \mathrm{ml}$ sterilin polystyrene container containing $25 \mathrm{ml}$ of $10 \%$ sucrose in PBS solution used as cryoprotectant. Similarly, the free cells were re-suspended in $10 \mathrm{ml}$ of $10 \%$ sucrose in PBS solution. Both immobilized and free cell suspensions in sucrose solutions were incubated at room temperature for $1 \mathrm{~h}$ and then frozen at $-80{ }^{\circ} \mathrm{C}$ for $24 \mathrm{~h}$. The frozen cultures were then freeze-dried in a IEC Lyoprep 3000 freeze-dryer (Lyoprep, Dunstable, UK) for approximately 2-4 days. The viable cell concentration were measured both pre- and post-freeze-drying. The water activity of freeze-dried powders in all cases was $\sim 0.07$. Each experiment was conducted in triplicate.

\subsection{Adhesion of Lactobacillus cells to Caco-2 cells}

Adhesion of the Lactobacillus cells to Caco-2 cells was studied as described previously (Deepika, Green, Frazier, \& Charalampopoulos, 2009). The Caco-2 cell line was cultured in Eagle's Minimum Essential Medium (EMEM, Lonza, UK) supplemented with $10 \%$ Fetal Bovine Serum (FBS), $1 \%$ mixture penicillinstreptomycin solution and $1 \%$ non-essential amino acid solution at $37{ }^{\circ} \mathrm{C}$ in an atmosphere of $5 \% \mathrm{CO}_{2}$ and $95 \%$ relative humidity. After 21 days, the six-well tissue 
culture plate was ready to use as the cells were fully differentiated. One day prior to the adhesion assay, the Caco- 2 cells were fed with the above culture medium, but without the presence of antibiotics. Before adhesion, the Caco-2 monolayer was washed twice with Dulbecco's phosphate buffered saline (DPBS, Lonza) in order to remove all traces of the medium. The number of the fully differentiated cells was counted using a Nikon microscope (Kingston upon Thames, UK) and was found to be around $5 \times 10^{5}$ cells $/ \mathrm{ml}$ in all cases. Then, $10 \mathrm{ml}$ of free or $1 \mathrm{~g}$ of immobilized bacterial cells (wet or freeze dried) were washed once with DPBS and then were resuspended in DPBS to obtain an approximate concentration of around $10^{8}-10^{9}$ $\mathrm{CFU} / \mathrm{ml}$ and $1 \mathrm{ml}$ of the bacterial suspension was added to each well. The plates were incubated at $37{ }^{\circ} \mathrm{C}$ in $5 \% \mathrm{CO}_{2}$ and $95 \%$ air. After $1 \mathrm{~h}$, the supernatant was removed from the wells and the wells were washed twice with DPBS. Subsequently, $1 \mathrm{ml}$ of DPBS was added to each well and the monolayer was scalped and transferred to $9 \mathrm{ml}$ of $1 / 4$ Ringer's solution. The number of probiotic cells bound to the Caco- 2 cells was determined after serial dilutions and plating in MRS agar plates. Adhesion of Lactobacillus strains was expressed as the number of viable bacteria adhering to 100 Caco-2 cells. Each experiment was conducted in triplicate.

\subsection{Adhesion to $n$-hexadecane}

The microbial adhesion to $n$-hexadecane (MATH assay) was employed to study the hydrophobicity of free and immobilized cells and was carried out as described previously (Deepika et al., 2009). In brief, $10 \mathrm{ml}$ of free or $1 \mathrm{~g}$ of immobilized bacteria (wet or freeze-dried) were washed with PBS and suspended in $10 \mathrm{mM} \mathrm{KH}_{2} \mathrm{PO}_{4}$ to obtain an $\mathrm{OD}_{600} \sim 0.8$. The $\mathrm{pH}$ was adjusted to 3.0 with $1 \mathrm{M} \mathrm{HCl}$ and then $2 \mathrm{ml}$ of the bacterial suspension were mixed with equal volume of $n$ hexadecane. The mixture was vortexed for $1 \mathrm{~min}$ and was allowed undisturbed to rest 
for $20 \mathrm{~min}$ to achieve a complete phase separation. The aqueous phase was removed and the $\mathrm{OD}_{600}$ was measured. The level of adhesion to $n$-hexadecane was expressed as the $\%$ percentage adhesion according to the following equation:

$$
\% \text { Adhesion to hexadecane }=\left(\frac{1-A_{1}}{A o}\right) \times 100
$$

where $\mathrm{A}_{0}$ : initial absorbance, $\mathrm{A}_{1}$ : absorbance after 20 min of incubation. The MATH assay was conducted in triplicate for each sample.

\subsection{Trans-epithelial electrical resistance (TEER) assay}

TEER was used to measure the levels of tight junction in intestinal epithelial cells according to a method described previously (Commane et al., 2005). Cell culture inserts $(0.4 \mu \mathrm{m}$, Becton Dickinson) were coated with $0.1 \%$ type I rat-tail collagen (Sigma-Aldrich Company Ltd., Dorset, UK) and left to dry overnight under a UV light in six-well plates (Becton Dickinson). Caco-2 cells were seeded into the inserts at $2.5 \mathrm{~mL}$ aliquots per well with a concentration of $5 \times 10^{5}$ cells $/ \mathrm{ml}$, as described above (Section 2.4). Eagle's Minimum Essential Medium (EMEM, Lonza) supplemented with $10 \%$ Fetal Bovine Serum (FBS), $1 \%$ mixture penicillinstreptomycin solution and $1 \%$ non-essential amino acid solution $(2 \mathrm{ml}$ of culture medium) was added to the basal compartment of each well. The cells were grown at $37{ }^{\circ} \mathrm{C}$ in an atmosphere of $5 \% \mathrm{CO}_{2}$ and $95 \%$ relative humidity. The culture medium was refreshed every 2 days. After 12 days of culturing, the integrity of the monolayer was evaluated by measuring the TEER using an EVOM epithelial voltohmmeter chopstick electrode (World Precision Instruments, Stevenage, UK). Readings were performed every $24 \mathrm{~h}$ until the TEER values stabilized (day 16). TEER at time zero was determined before bacterial samples were added to the monolayer. Then, the culture medium from both the apical and basal compartments was removed and immediately $2 \mathrm{ml}$ bacterial samples were added in the apical side $\left(10^{8}-10^{9} \mathrm{CFU} / \mathrm{ml}\right)$, 
while $2 \mathrm{ml}$ medium were added in the basal compartments. The cells were maintained for $1 \mathrm{~h}$ at $37{ }^{\circ} \mathrm{C}$ in an atmosphere of $5 \% \mathrm{CO}_{2}$ and $95 \%$ relative humidity. Then, the culture medium and the bacterial sample were removed and the apical side was washed with $2 \mathrm{ml}$ DPBS. Thereafter, in both the apical and basal compartments, $2 \mathrm{ml}$ of culture medium were applied and TEER readings were recorded after $1,1.5$ and 17 $\mathrm{h}$ in order to estimate the potential increase in TEER. One insert/well in every falcon was left without bacteria as a negative control. The percentage change in TEER was expressed according to the following equation:

$$
\% \text { change in TEER }=\left[\frac{(T 1-T 0)}{T 0}\right] \times 100
$$

where T0: TEER at time zero, T1: TEER after $1 \mathrm{~h}, 1.5 \mathrm{~h}$ and $17 \mathrm{~h}$. Each experiment was conducted in triplicate.

\subsection{Scanning electron microscopy (SEM)}

Monolayers of Caco-2 cells were grown on glass coverslips as described previously (Chauviere, Coconnier, Kerneis, Fourniat, \& Servin, 1992). Briefly, Caco2 cells were prepared on glass coverslips which were placed in six-well tissue culture plates. Cells were grown in culture medium at $37{ }^{\circ} \mathrm{C}$ in $5 \% \mathrm{CO}_{2}$ and $95 \%$ air. After the bacterial adhesion assay, the cells were fixed with $2.5 \%$ glutaraldehyde in $0.1 \mathrm{M}$ sodium phosphate buffer ( $\mathrm{pH}$ 7.4) for $1 \mathrm{~h}$ at room temperature. Then, washing with 2 $\mathrm{ml}$ of the phosphate buffer was performed and the cells were osmicated for $30 \mathrm{~min}$ with $2 \% \mathrm{OsO}_{4}$ and washed again 3 times with the same buffer. The coverslips were gradually dehydrated with $30 \%$ ethanol for $15 \mathrm{~min}, 50 \%$ for $15 \mathrm{~min}, 70 \%$ for 15 min, $80 \%$ for $15 \mathrm{~min}, 90 \%$ for $15 \mathrm{~min}$, and $3 \times 100 \%$ for $15 \mathrm{~min}$ to achieve absolute dry samples. The cells were further dried in a critical-point dryer (Balzers CPD 030) and coated with gold. The samples were imaged using a FEI Quanta 600 FEG scanning electron microscope. Bacterial attachment was evaluated by scanning 
electron microscopy using a fixed number of monolayer cells $\left(5 \times 10^{5}\right.$ cells/well $)$ and bacteria (8.2 log CFU added per well).

\subsection{Experimental design and statistical analysis}

All treatments were carried out in triplicate. The experiments were designed and analyzed statistically by ANOVA. Duncan's multiple range test was used to determine significant differences among results (coefficients, ANOVA tables and significance $(P<0.05)$ were computed using Statistica v.5.0).

\section{Results and Discussion}

Cell immobilization techniques are usually applied in order to maintain cell viability, activity and functionality during food production, processing and storage (Deepika, Rastall, \& Charalampopoulos, 2011; Lopez-Rubio, Gavara, \& Lagaron, 2006), and during passage through the GI tract (Saxami et al., 2012; Sidira et al., 2010). In order to confer a health effect, high adhesion ability of the probiotic cells is required (Ouwehand \& Salminen, 2003). Despite the considerable amount of research aiming at evaluating the adhesion properties of free cells and the potential interaction between probiotics and the host (Ouwehand \& Salminen, 2003; Tuomola \& Salminen, 1998), there is limited knowledge on how the food matrix influences the adhesion ability of probiotics (Burgain et al., 2014; Endo et al., 2014; Bove et al. 2013). This is important for the design of novel foods that are able to maintain high cell viability and functionality.

To the best of our knowledge, this is the first report concerning the investigation of the effect of the immobilization support on the adhesion properties of probiotic bacteria. The strategy adopted was to use the model probiotic strains $L$. casei ATCC 393 and L. plantarum NCIMB 8826, which were immobilized on wheat 
grains. Wheat grains were previously used as immobilization supports of $L$. casei ATCC 393 (Bosnea et al., 2009) and the immobilized cells were incorporated in traditional foods to confer probiotic properties (Sidira et al., 2014a; Sidira, Galanis, Nikolaou, Kanellaki, \& Kourkoutas, 2014b). In addition, the effect of freeze-drying was also evaluated because wet cells are incompatible with commercial and industrial needs, which require robust cultures that can maintain their availability during storage.

\subsection{Immobilization and freeze-drying of lactobacilli}

The results concerning the effect of freeze-drying on the viability of free and immobilised lactobacilli onto wheat grains are presented in Figure 1. It can be observed that freeze-drying had no significant $(P>0.05)$ effect on cell survival for both free and immobilized cells and that high cell concentrations were obtained post freeze-drying in all cases.

\subsection{Adhesion to Caco-2 cells}

The results concerning the adhesion abilities of both $L$. casei ATCC 393 and $L$. plantarum NCIMB 8826 to Caco-2 cells are presented in Figure 2, and indicate that both strains showed considerable adhesion ability to Caco-2 cells (>1000 CFU/100 Caco-2 cells for free wet cells). These values were higher than those reported in previous studies for other lactobacilli, which ranged between 0.9 and 900 CFU/100 Caco-2 cells (Ren et al., 2012; Bogovic-Matijasic, Narat, \& Zori, 2003; Chauviere et al., 1992; Bernet, Brassart, Neeser, \& Servin., 1994; Sarem, Sarem-Damerdji, \& Nicolas, 1996; Coconnier, Klaenhammer, Kerneis, Bernet, \& Servin, 1992). A cell concentration of 8-9 $\log \mathrm{CFU} / \mathrm{ml}$ of Lactobacillus was added to the Caco-2 culture, as 
this is the recommended concertation for probiotics in order to exert a beneficial effect in the gut.

Although cell immobilization resulted in a significant reduction of adhesion ability (>100 CFU/100 Caco-2 cells for immobilized wet cells), adhesion still remained in satisfactory levels compared to values reported in literature concerning free cells (0.9-900 CFU/100 Caco-2 cells) (Bogovic-Matijasic et al., 2003; Chauviere et al., 1992; Bernet et al., 1994; Ren et al., 2012; Sarem et al., 1996; Coconnier et al., 1992).

Freeze-drying had a negative effect on the adhesion properties of free cells, but not of immobilized cells. The adhesion to Caco-2 cells decreased significantly for free cells (86\% and $71 \%$ reduction for L. plantarum and L. casei, respectively). According to Henriksson, Szewzyk, \& Conway, (1991) the adhesion of lactobacilli is most probably mediated by a proteinaceous component on the bacterial surface. Bacterial surface layers (S-layers) are composed of protein monomers arranged in crystalline arrays (Callegari et al., 1998) and it appears that freeze-drying can induce the detachment of S-layers monomers from the cell wall of lactobacilli (Ray \& Johnson, 1986). This cell surface damage that occurs during freeze-drying may provide an explanation of the results above. Nevertheless, the adhesion values still were comparable to those recorded in the literature for free dried cells, ranging from 3-325 CFU/100 Caco-2 cells (Bogovic-Matijasic et al., 2003; Chauviere et al., 1992; Bernet et al., 1994).

The adoption of functional criteria (adherence to human cell lines, resistance to gastric acidity and bile acids) for the in vitro selection of probiotic bacteria can result in the isolation of strains capable of performing effectively in the GI tract and that may reflect certain in vivo effects on the host (Dunne et al., 2001). A previous 
study has shown how in vitro methods can be used for prediction of the survival potential of lactobacilli in the human GI tract (Jacobsen et al., 1999), although Lebeer at al., (2010a) has shown that in vitro studies are not related with survival in vivo. Our results validated the suggestions of Busscher \& Weerkamp (1987), according to which the role of hydrophobic cells, supposed to be associated with bacterial surface appendages, is suggested to be its dehydrating capacity, allowing the removal of the water film and yielding a small area of direct contact between the protuberant parts of the cell surface and the substrate. Noticeably, the ability of probiotics to remove vicinal water depends greatly on the strain used.

\subsection{Adhesion to $n$-hexadecane}

Figure 3 shows the results from the MATH assay for wet and freeze-dried cells. The results indicated that the L. casei strain was relatively hydrophilic compared to the $L$. plantarum strain $(54.8 \%$ and $22.7 \%$ for free cells of $L$. plantarum and $L$. casei, respectively). Immobilization affected $(P<0.05)$ positively the adhesion only for L. casei. On the other hand, although freeze-drying resulted in increased $(P<0.05)$ adhesion ability for $L$. plantarum (both free and immobilized) and for immobilized $L$. casei, it had no effect $(P>0.05)$ on free $L$. casei cells.

Cell surface hydrophobicity has been associated with bacterial adhesion to a variety of surfaces (Marin et al., 1997). The consensus is that high hydrophobicity of bacteria results in greater attractive forces and higher levels of adhesion to Caco-2 cells, whereas smaller results in lower levels of adhesion (Rijnaarts, Norde, Bouwer, Lyklema, \& Zehnder, 1993). According to Reid et al. (1992), the surface hydrophobicity of Lactobacillus strains varies greatly. In the present study, the results indicated that L. casei ATCC 393 strain was relatively hydrophilic (33.3\% adhesion to $n$-hexadecane), whereas L. plantarum NCIMB 8826 is characterized as hydrophobic 
( $42.86 \%$ adhesion to $n$-hexadecane). Similar results were obtained by Pelletier et al., (1997) and Harty, Patrikakis, and Knox (1993) concerning the L. casei cells and by Zavisic et al., (2011), Jamaly, Benjouad, and Bouksaim (2011) and Abdulla, Abed, and Saeed (2014) concerning the L. plantarum cells.

However, no correlation between adhesion ability to the Caco-2 monolayer and hydrophobicity was observed for immobilized L. casei ATCC 393. Although the strain was characterized as relatively hydrophilic, the number of adhered immobilized L. casei was higher than immobilized L. plantarum (154 to $104 \mathrm{CFU}$ adhered per 100 Caco-2 cells, respectively). The opposite results were observed in free cells, as hydrophobicity correlated well with adhesion ability (1038 and 2349 CFU adhered per 100 Caco-2 cells for L. plantarum and L. casei, respectively). A possible explanation for these observations might be that the immobilized cells do not have direct access to the Caco-2 cells (Figure 4). The inability to correlate hydrophobicity with adhesion to the Caco-2 monolayer is most likely due to many factors that are involved in the adhesion of lactobacilli (Azuma \& Sato, 2001). Cell surface hydrophobicity is one of the physico-chemical properties that facilitate the first contact between the microorganism and the host cells. This non-specific initial interaction is weak and reversible and precedes the subsequent adhesion process mediated by more specific mechanisms involving cell-surface proteins and lipoteichoic acids (Schillinger, Guigas, \& Holzapfel, 2005). Bacterial cell surface macromolecules may interact with host pattern recognition receptors (PRRs) of the GI mucosa and elicit specific responses in the intestinal system (Bron, Baarlen, \& Kleerebezem, 2012; Lebeer, Vanderleyden, \& Keersmaecker, 2010b). As stated above, structural damage (S-layer) of bacteria during freeze-drying can affect the adhesion ability (Callegari et al., 1998) and reduce its cell surface hydrophobicity 
significantly (Bruinsma, van der Mei, \& Busscher, 2001). It therefore appears that the adhesion was not caused by hydrophobic interaction. According to Schillinger et al., (2005), hydrophobicity is not a prerequisite for a strong adherence capacity.

\subsection{Trans-Epithelial Electrical Resistance Assay}

The most sensitive measure of mucosal barrier function is transepithelial electrical resistance (TEER), as it reflects the degree to which ions traverse tissue (Blikslager, Moeser, Gookin, Jones, \& Odle, 2007). When TEER is increased, the tight junction between the cells becomes stronger and the permeability of the monolayer is decreased (Mattar, Drongowski, Coran, \& Harmon, 2001). The TEER ratio was measured before adding the bacterial inoculum (time zero), and after addition and incubation of the probiotic strains in Caco-2 monolayer. The results from the TEER assay are presented in Table 1. For all samples, the TEER values increased with incubation time, reaching the maximum after $17 \mathrm{~h}$ of incubation.

The results indicated that both wet and freeze-dried free cells led to an increase in TEER values (58.4 and $43.6 \%$ for wet L. plantarum and L. casei, respectively, and 73.6 and $73.7 \%$ for freeze-dried L. plantarum and L. casei, respectively). Similar results were also published previously reporting increases in TEER by $20-158 \%$ for L. plantarum (Anderson et al., 2010a, 2010b) and 6-87 \% for L. casei cells (Fang et al., 2010). However, significantly $(P<0.05)$ higher increase was recorded for immobilized cells (151 and $170 \%$ for wet L. plantarum and L. casei, respectively, and 151 and $121 \%$ for freeze-dried L. plantarum and L. casei, respectively). Notably, immobilized cells resulted in TEER values at least 2 -fold higher than free cells, highlighting the positive effects of cell immobilization in enhancing the persistence of probiotic cells in the Caco-2 monolayer. It is thus suggested that immobilized cells act as a protective shield against intestinal 
permeability, which might be due to increased physical interactions between the immobilised bacterial cells and the Caco-2 cells, or possibly due to increased synthesis of short chain fatty acids, which are known to be important nutrients for intestinal epithelial cells (Mangell et al., 2002). Improved epithelial barrier function has been previously associated with synbiotic food products containing immobilized probiotic microorganisms on prebiotic fibres (Commane et al., 2005). The findings of this study are expected to have a significant impact in the development of novel probiotic products targeting a range of GI disorders, as they indicated that cell immobilization, which has been suggested for the production of probiotic products (Kourkoutas et al., 2006; Bosnea et al., 2009; Sidira et al., 2014a, 2014b), can potentially offer the additional benefit of increased probiotic barrier function.

\subsection{Scanning electron microscopy (SEM)}

Figure 4 shows images from electron microscopy demonstrating key features of the Caco-2 cells, as well as the adhesion of the bacterial cells. It was noted that both immobilized and free cells adhered to the brush border microvilli and that the starch granules of wheat grains interacted with the Caco- 2 monolayer, confirming the results of adhesion and TEER assays. Importantly, the morphology of the monolayer with the expression of microvilli, the tight-junctions of the starch granules of wheat, and the immobilized cells onto wheat grains are also obvious. Similar photographs were obtained for L. plantarum NCIMB 8826 strain and for freeze-dried cells (data not shown).

\section{Conclusions}

In conclusion, the present study showed that immobilization onto wheat grains decreased significantly the adhesion ability of both L. casei ATCC 393 and $L$. plantarum NCIMB 8826 strains to Caco-2 monolayers most likely because 
421 immobilized cells did not have direct access to the Caco-2 cells. However, 422 immobilization led to a significant enhancement of the monolayer integrity, which is

423 compromised in a number of intestinal disorders, and is an important functional

424 attribute of probiotic strains. Overall, more in vitro and in vivo research is needed in 425 order to understand the effect of immobilization, which can also occur naturally 426 within a food matrix, on the functional properties of probiotics.

427

\section{Acknowledgments}

429 This research has been co-financed by the European Union (European Social Fund 430 ESF) and Greek national funds through the Operational Program "Education and 431 Lifelong Learning" of the National Strategic Reference Framework (NSRF) 432 Research Funding Program: Heracleitus II. Investing in knowledge society through 433 the European Social Fund. The authors wish also to aknowledge the contribution of 434 the Electron Microscopy Laboratory at the University of Reading for their help with 435 SEM. 


\section{References}

439 Abdulla, A. A., Abed, T. A., \& Saeed, A. M. (2014). Adhesion, Autoaggregation and Hydrophobicity of Six Lactobacillus Strains. British Microbiology Research Journal, 4, 381-391.

Anderson, R. C., Cookson, A. L., McNabb, W. C., Park, Z., McCann, M. J., Kelly, W. J., \& Roy, N. C. (2010a). Lactobacillus plantarum MB452 enhances the function of the intestinal barrier by increasing the expression levels of genes involved in tight junction formation. BMC Microbiology, 10, 316.

Anderson, R. C., Cookson, A. L., McNabb, W. C., Kelly, W. J., \& Roy, N. C. (2010b). Lactobacillus plantarum DSM2648 is a potential probiotic that enhances intestinal barrier function. FEMS Microbiology Letters, 309, 184-192.

Azuma, Y., \& Sato, M. (2001). Lactobacillus casei NY1301 increases the adhesion of Lactobacillus gasseri NY0509 to human intestinal Caco-2 cells. Bioscience, Biotechnology, and Biochemistry, 65, 2326-2329.

Bernet, M. F., Brassart, D., Neeser, J. R., \& Servin, A. L. (1994). Lactobacillus acidophilus LA 1 binds to cultured human intestinal cell lines and inhibits cell attachment and cell invasion by enterovirulent bacteria. Gut, 35, 483-489.

Blikslager, A. T., Moeser, A. J., Gookin, J. L., Jones, S. L., \& Odle, J. (2007). Restoration of Barrier Function in Injured Intestinal Mucosa. Physiological Reviews, $87,545-564$.

Bogovic-Matijasic, B., Narat, M., \& Zori, M. (2003). Adhesion of Two Lactobacillus gasseri Probiotic Strains on Caco-2 Cells. Food Technology and Biotechnology, 41, 83-88. 
Bosnea, L., Kourkoutas, Y., Albantaki, N., Tzia, C., Koutinas, A. A., \& Kanellaki, M. (2009). Functionality of freeze-dried L. casei cells immobilized on wheat grains. LWT-Food Science and Technology, 42, 1696-1702.

Bove, P., Russo, P., Capozzi, V., Gallone, A. Spano, G., Fiocco D. (2013) Lactobacillus plantarum passage through an oro-gastro-intestinal tract simulator: Carrier matrix effect and transcriptional analysis of genes associated to stress and probiosis. Microbiological Research, 168, 351-359.

Boylston, T. D., Vinderola, C. G., Ghoddusi, H. B., \& Reinheimer J. A. (2004). Incorporation of bifidobacteria into cheeses: Challenges and rewards. International Dairy Journal, 19, 315-387.

Bron, P. A., Baarlen, P., \& Kleerebezem, M. (2012). Emerging molecular insights into the interaction between probiotics and the host intestinal mucosa. Nature Reviews Microbiology, 10, 66-78.

Bruinsma, G. M., van der Mei, H. C., \& Busscher, H. J. (2001). Bacterial adhesion to surface hydrophilic and hydrophobic contact lenses. Biomaterials, 22, 3217-3224.

Burgain, J., Scher, J., Francius, G., Borges, F., Corgneau, M., Revol-Junelles, A. M., Cailliez-Grimal, C., Gaiani, C. (2014). Lactic acid bacteria in dairy food: Surface characterization and interactions with food matrix components. Advances in Colloid and Interface Science, 213, 21-35.

Busscher, H. J., \& Weerkamp, A. H. (1987). Specific and non-specific interactions in bacterial adhesion to solid substrata. FEMS Microbiology Reviews, 46, 165-173.

Charalampopoulos, D., Pandiella, S. S., \& Webb, C. (2002). Growth studies of potentially probiotic lactic acid bacteria in cereal-based substrates. Journal of Applied Microbiology, 92, 851-859. 
485 Charalampopoulos, D., \& Pandiella, S. S. (2010). Survival of human derived 486 Lactobacillus plantarum in fermented cereal extracts during refrigerated storage. 487 Food Science and Technology, 43, 431-435.

488 Nualkaekul, S., \& Charalampopoulos D. (2011). Survival of Lactobacillus plantarum 489 in model solutions and fruit juices. International Journal of Food Microbiology, 146, $490 \quad 111-117$.

491 Callegari, M. L., Riboli, B., Sanders, J. W., Cocconcelli, P. S., Kok, J., Venema, G., 492 \& Morelli, L. (1998). The Slayer gene of Lactobacillus helveticus CNRZ 892: 493 cloning, sequence and heterologous Expression. Microbiology, 144, 719-726.

494 Chauviere, G., Coconnier, M. H., Kerneis, S., Fourniat, J., \& Servin, A.L. (1992). 495 Adhesion of human Lactobacillus acidophilus strain LB to human enterocyte-like 496 Caco-2 cells. Journal of General Microbiology, 138, 1689-1696.

497 Coconnier, M. H., Klaenhammer, T. R., Kerneis, S., Bernet, M. F. \& Servin, A. L., 498 (1992). Protein-Mediated Adhesion of Lactobacillus acidophilus BG2FO4 on Human 499 Enterocyte and Mucus-Secreting Cell Lines in Culture. Applied and Environmental 500 Microbiology, 58, 2034-2039.

501 Commane, D. M., Shortt, C. T., Silvi, S., Cresci, A., Hughes R. M., \& Rowland I. R. 502 (2005). Effects of Fermentation Products of Pro- and Prebiotics on Trans-Epithelial 503 Electrical Resistance in an In Vitro Model of the Colon. Nutrition and Cancer, 51, $504 \quad 102-109$.

505 Deepika, G., Green, R. J., Frazier, R. A., \& Charalampopoulos, D. (2009). Effect of 506 growth time on the surface and adhesion properties of Lactobacillus rhamnosus GG. 507 Journal of Applied Microbiology, 107, 1230-1240. 
Deepika, G., Rastall, R. A., \& Charalampopoulos D. (2011). Effect of Food Models and Low-Temperature Storage on the Adhesion of Lactobacillus rhamnosus GG to Caco-2 Cells. Journal of Agricultural and Food Chemistry, 59, 8661-8666.

Deshpandea, G., Rao, S., \& Patolea S. (2011). Progress in the field of probiotics: year 2011. Current Opinion in Gastroenterology, 27, 13-18.

Dimitrellou, D., Kourkoutas, Y., Koutinas, A. A., \& Kanellaki, M. (2009). Thermallydried immobilized kefir on casein as starter culture in dried whey cheese production. Food Microbiology, 26, 809-820.

Douillard, F. P., Ribbera, A., Kant, R., Pietila, T. E., Jarvinen, H. M., Messing, M., Randazzo, C. L., Paulin, L., Laine, P., Ritari, J., Caggia, C., Lahteinen, T., Brouns, S. J. J., Satokari, R., Ossowski, I., Reunanen, J., Palva, A., \& Vos, W. M. (2013). Comparative Genomic and Functional Analysis of 100 Lactobacillus rhamnosus Strains and Their Comparison with Strain GG. Plos Genetics, 9, e1003683. doi: 10.1371/journal.pgen.1003683.

Duary, R. K., Rajput, Y. S., Batish, V. K., \& Grover, S. (2011). Assessing the adhesion of putative indigenous probiotic lactobacilli to human colonic epithelial cells. Indian Council of Medical Research, 134, 664-671.

Dunne, C., O’Mahony, L., Murphy, L., Thornton, G., Morrissey, D., O’Halloran, S., Feeney, M., Flynn, S., Fitzgerald, G., Daly, C., Kiely, B., O’Sullivan, G. C., Shanahan, F., \& Collins, J. K. (2001). In vitro selection criteria for probiotic bacteria of human origin: correlation with in vivo findings. The American Journal of Clinical Nutrition, 73, 386S-392S.

Elo, S., Saxelin, M., \& Salminen, S. (1991). Attachment of Lactobacillus casei strain GG to human colon carcinoma cell line Caco-2: comparison with other dairy strains. Letters in Applied Microbiology, 13, 154-156. 
533 Endo, A., Teräsjärvi, J., Salminen, S. (2014). Food matrices and cell conditions 534 influence survival of Lactobacillus rhamnosus GG under heat stresses and during 535 storage. International Journal of Food Microbiology, 174, 110-112.

536 Fang H. W., Fang, S. B., Chiau J. S. C., Yeung, C. Y., Chan, W. T., Jiang, C. B.,

537 Cheng, M. L., \& Lee, H. C. (2010). Inhibitory effects of Lactobacillus casei subsp. 538 rhamnosus on Salmonella lipopolysaccharide-induced inflammation and epithelial 539 barrier dysfunction in a co-culture model using Caco-2/ peripheral blood mononuclear 540 cells. Journal of Medical Microbiology, 59, 573-579.

541 Harty, D. W. S., Patrikakis, M., \& Knox, K. W. (1993). Identification of 542 Lactobacillus Strains Isolated from Patients with Infective Endocardi tis and 543 Comparison of their Surface-associated Properties with those of Other Strains of the 544 Same Species. Microbial Ecology in Health and Disease, 6, 191-201.

545 Hempel, S., Newberry, S. J., Maher, A. R., Wang, Z., Miles, J. N. V., Shanman, R., 546 Johnsen, B., \& Shekelle, P. G. (2012). Probiotics for the Prevention and Treatment of 547 Antibiotic-Associated Diarrhea A Systematic Review and Meta-analysis. Journal of 548 the American Medical Association, 307, 1959-1969.

549 Henriksson, A., Szewzyk, R., \& Conway, P. L. (1991). Characteristics of the 550 Adhesive Determinants of Lactobacillus fermentum 104. Applied and Environmental 551 Microbiology, 499-502.

552 Hilgendorf, C., Spahn-Langguth, H., Regardh, C. G., Lipka, E., Amidon, G.L., \& 553 Langguth, P. (2000). Caco-2 versus Caco-2/HT29-MTX co-cultured cell lines: 554 Permeabilities via diffusion, inside- and outside-directed carrier-mediated transport. 555 Journal of Pharmaceutical Sciences, 89, 63-75.

556 Izquierdo, H., Horvatovich, P., Marchioni, E., Aoude-Werner, D., Sanz, Y., \& 557 Ennahar, S. (2009). 2-DE and MS analysis of key proteins in the adhesion of 
Lactobacillus plantarum, a first step toward early selection of probiotics based on bacterial biomarkers. Electrophoresis, 30, 949-956.

Jacobsen, C. N., Nielsen, V. R., Hayford, A. E., Moller, P. L., Michaelsen, K. F., Pærregaard, A., Sandström, B., Tvede, M., \& Jakobsen, M. (1999). Screening of Probiotic Activities of Forty-Seven Strains of Lactobacillus spp. by In Vitro Techniques and Evaluation of the Colonization Ability of Five Selected Strains in Humans. Applied and Environmental Microbiology, 65, 4949-4956.

Jamaly, N., Benjouad A. \& Bouksaim M. (2011). Probiotic Potential of Lactobacillus strains Isolated from Known Popular Traditional Moroccan Dairy Products. British Microbiology Research Journal, 1, 79-94.

Karczewski, J., Troost, F. J., Konings, I., Dekker, J., Kleerebezem, M., Brummer R. J. M., \& Wells, J. M. (2010). Regulation of human epithelial tight junction proteins by Lactobacillus plantarum in vivo and protective effects on the epithelial barrier. American journal of physiology - Gastrointestinal and Liver Physiology, 298, G851G859.

Kechagia, M., Basoulis, D., Konstantopoulou, S., Dimitriadi, D., Gyftopoulou, K., Skarmoutsou, N., \& Fakiri, E. M. (2013). Health Benefts of Probiotics: A Review. ISRN Nutrition, 1-7.

Kinoshita, H., Uchida, H., Kawai, Y., Kawasaki, T., Wakahara, N., Matsuo, H., Watanabe, M. Kitazawa, H., Ohnuma, S., Miura, K., Horii, A., \& Saito T. (2008). Cell surface Lactobacillus plantarum LA 318 glyceraldehyde-3-phosphate dehydrogenase (GAPDH) adheres to human colonic mucin. Journal of Applied Microbiology, 104, 1667-1674.

Klingberg, T. D., Pedersen, M. H., Cencic, A., \& Budde, B. B. (2005). Application of Measurements of Transepithelial Electrical Resistance of Intestinal Epithelial Cell 
583

584 Microbiology, 71, 7528-7530.

585 Kourkoutas, Y., Xolias, V., Kallis, M., Bezirtzoglou, E., \& Kanellaki M. (2005).

586 Lactobacillus casei immobilization on fruit pieces for probiotic additive, fermented 587 milk and lactic acid production. Process Biochemistry, 40, 411-416.

588 Kourkoutas, Y., Bosnea, L., Taboukos, S., Baras, C., Lambrou, D., \& Kanellaki, M. 589 (2006). Probiotic cheese production using Lactobacillus casei cells immobilized on 590 fruit pieces. Journal of Dairy Science, 89, 1439-1451.

591 Lebeer, S., Claes, I. J. J., Verhoeven, T. L. A., Vanderleyden, J., \& Keersmaecker, S. 592 C. J. (2010a). Exopolysaccharides of Lactobacillus rhamnosus GG form a protective 593 shield against innate immune factors in the intestine. Microbial Biotechnology, 4, $594 \quad 368-374$.

595 Lebeer, S., Vanderleyden, J., \& Keersmaecker, S. C. J. (2010b). Host interactions of 596 probiotic bacterial surface molecules: comparison with commensals and pathogens, 597 Nature Reviews Microbiology, 8, 171-184.

598 Lopez-Rubio, A., Gavara, R., \& Lagaron, J. M. (2006). Bioactive packaging: turning 599 foods into healthier foods through biomaterials. Trends in Food Science and 600 Technology, 17, 567-575.

601 Mangell, P., Nejdfors, P., Wang, M., Ahrne, S., Westrom, B., Thorlacius, H., \& 602 Jeppsson, B. (2002). Lactobacillus plantarum 299v inhibits Escherichia coli induced 603 intestinal permeability. Digestive Diseases and Sciences, 47, 511-516,

604 Marin, M. L., Benito, Y., Pin, C., Fernández, M. F., García, M. L., Selgas, M. D., \& 605 Casas, C. (1997). Lactic acid bacteria: hydrophobicity and strength of attachment to 606 meat surfaces. Letters in Applied Microbiology, 24, 14-18. 
607

608

609

610

611

612

613

614

615

616

617

618

619

620

621

622

623

624

625

626

627

628

629

630

631

Mattar, A. F., Drongowski, R. A., Coran, A. G., \& Harmon, C. M. (2001). Effect of probiotics on enterocyte bacteria translocation in vitro. Pediatric Surgery International, 17, 265-268.

Mattila-Sandholm, T., Myllarinen, P., Crittenden, R., Mogensen, G., Fonden, R., \& Saarela, M. (2002). Technological challenges for future probiotic foods. International Dairy Journal, 12, 173-182.

Nagpal, R., Kumar, A., Kumar, M., Behare, P. V., Jain, S., \& Yadav, H. (2012).

Probiotics, their health benefits and applications for developing healthier foods: a review. FEMS Microbiology Letters, 334, 1-15.

Oliveira, R., Azeredo, J., Teixeira, P., \& Fonseca, A. P. (2001). The role of hydrophobicity in bacterial adhesion. Meeting of the Biofilm Club, BioLine (pp. 1122). Powys, UK.

Ouwehand, A. C., \& Salminen, S. (2003). In vitro Adhesion Assays for Probiotics and their in vivo NYH6 Relevance: A Review. Microbial Ecology in Health and Disease, $15,175-184$.

Pelletier, C., Bouley, C., Cayuela, C., Bouttier, S., Bourlioux, P., \& Bellon-Fontaine, M. N. (1997). Cell Surface Characteristics of Lactobacillus casei subsp. casei, Lactobacillus paracasei subsp. paracasei, and Lactobacillus rhamnosus Strains. Applied and Environmental Microbiology, 63, 1725-1731.

Ray, B., \& Johnson, M. C. (1986). Freeze-drying injury of surface layer protein and its protection in Lactobacillus acidophilus. Cryo Letters, 7, 210-217.

Reid, G., Cuperus, P. L., Bruce, A. W., van der Mei, H., Tomeczek, L., Khoury, A. H., \& Buscher, H. J. (1992). Comparison of Contact Angles and Adhesion to Hexadecaneof Urogenital, Dairy, and Poultry Lactobacilli: Effect of Serial Culture Passages. Applied and Environmental Microbiology, 58, 1549-1553. 
632

633

634

635

636

637

638

639

640

641

642

643

644

645

646

647

648

649

650

651

652

653

654

655

Ren, D., Li, C., Qin, Y., Yin, R., Li, X., Tian, M., Du, S., Guo, H., Liu, C., Zhu, N.,

Sun, D., Li, Y., \& Jin, N. (2012). Inhibition of Staphylococcus aureus adherence to

Caco-2 cells by lactobacilli and cell surface properties that influence attachment.

Anaerobe, 18, 508-515.

Rijnaarts, H. H. M., Norde, W., Bouwer, E. J., Lyklema, J., \& Zehnder, A. J. B. (1993). Bacterial Adhesion under Static and Dynamic Conditions. Applied and Environmental Microbiology, 59, 3255-3265.

Ritchie, M. L., \& Romanuk, T. N. (2012). A Meta-Analysis of Probiotic Efficacy for Gastrointestinal Diseases. Plos One, 7, e34938-e34938. doi: 10.1371/journal.pone.0034938.

Sarem, F., Sarem-Damerdji, L. O., \& Nicolas, J. P. (1996). Comparison of the adherence of three Lactobacillus strains to Caco-2 and lnt-407 human intestinal cell lines. Letters in Applied Microbiology, 22, 439-442.

Saxami, G., Ypsilantis, P., Sidira, M., Simopoulos, C., Kourkoutas, Y., \& Galanis, A. (2012). Distinct adhesion of probiotic strain Lactobacillus casei ATCC 393 to rat intestinal mucosa. Anaerobe, 18, 417-420.

Schillinger, U., Guigas, C., \& Holzapfel, W. H. (2005). In vitro adherence and other properties of lactobacilli used in probiotic yoghurt-like products. International Dairy Journal, 15, 1289-1297.

Segers, M. E., \& Lebeer, S. (2014). Towards a better understanding of Lactobacillus rhamnosus GG - host interactions. Microbial Cell Factories, 13, S1-S7.

Siaterlis, A., Deepika, G., \& Charalampopoulos, D. (2009). Effect of culture medium and cryoprotectants on the growth and survival of probiotic lactobacilli during freeze drying. Letters in Applied Microbiology, 48, 295-301. 
Sidira, M., Karapetsas, A., Galanis, A., Kanellaki, M., \& Kourkoutas, Y. (2014a). Effective survival of immobilized Lactobacillus casei during ripening and heat treatment of probiotic dry-fermented sausages and investigation of the microbial dynamics. Meat Science, 96, 948-955.

Sidira, M., Galanis, A., Nikolaou, A., Kanellaki, M., \& Kourkoutas, Y. (2014b). Evaluation of Lactobacillus casei ATCC 393 protective effect against spoilage of probiotic dry-fermented sausages. Food Control, 42, 315-320.

Sidira, M., Saxami, G., Dimitrellou, D., Santarmaki, V., Galanis, A., \& Kourkoutas, Y. (2013). Monitoring survival of Lactobacillus casei ATCC 393 in probiotic yogurts using an efficient molecular tool. Journal of Dairy Science, 96, 3369-3377.

Sidira, M., Galanis, A., Ypsilantis, P., Karapetsas, A., Progaki, Z., Simopoulo, C., \& Kourkoutas Y. (2010). Effect of probiotic-fermented milk administration on gastrointestinal survival of Lactobacillus casei ATCC 393 and modulation of intestinal microbial flora. Journal of Molecular Microbiology and Biotechnology, 19, $224-230$.

Tuomola, E. M., \& Salminen, S. J. (1998). Adhesion of some probiotic and dairy Lactobacillus strains to Caco-2 cell cultures. International Journal of Food Microbiology, 41, 45-51.

van der Mei, H. C., van der Belt- Gritter, B., Pouwels, P. H., Martinez, B., \& Busscher, H. J. (2003). Cell surface hydrophobicity is conveyed by S-layer proteins a study in recombinant lactobacilli. Colloids and Surfaces B: Biointerfaces, 28, 127134.

Zavisic, G., Radulovic, Z., Vranic, V., Begovic, J., Topisirovic L., \& Strahinic, I. (2011). Characterization and antimicrobial activity of vaginal Lactobacillus isolate. Archives of Biological Sciences, 63, 29-35. 
Table 1. Changes in Trans-Epithelial Electrical Resistance (TEER) values of Caco-2

683 cells in the presence of L. plantarum NCIMB 8826 and L. casei ATCC 393 cells.

684 Changes are expressed as percentage change in TEER values. Significant differences

$685(P<0.05)$ are indicated by different letters in superscript.

686

\begin{tabular}{|c|c|c|c|c|c|}
\hline \multirow[b]{2}{*}{ Strain } & \multirow[b]{2}{*}{ Time (h) } & \multicolumn{2}{|c|}{ Free } & \multicolumn{2}{|c|}{ Immobilized } \\
\hline & & Wet & Freeze-dried & Wet & Freeze-dried \\
\hline \multirow[t]{3}{*}{ L. plantarum NCIMB 8826} & 1.0 & $-1.8 \pm 0.1^{\mathrm{a}}$ & $6.2 \pm 0.3^{\mathrm{b}}$ & $32.6 \pm 1.6^{\mathrm{c}}$ & $8.45 \pm 0.4^{\mathrm{d}}$ \\
\hline & 1.5 & $25.7 \pm 5.3^{\mathrm{c}, \mathrm{e}}$ & $18.9 \pm 0.6^{\mathrm{f}}$ & $111.6 \pm 38.8^{\mathrm{g}}$ & $47.3 \pm 23.1^{\mathrm{h}}$ \\
\hline & 17.0 & $58.4 \pm 10.3^{\mathrm{h}}$ & $73.6 \pm 29.9^{\mathrm{g}, \mathrm{h}, \mathrm{i}, \mathrm{j}, \mathrm{k}}$ & $150.8 \pm 54.6^{\mathrm{i}, 1, \mathrm{p}}$ & $150.7 \pm 33.1^{\mathrm{i}, 1, \mathrm{p}}$ \\
\hline \multirow[t]{3}{*}{ L. casei ATCC 393} & 1.0 & $13.9 \pm 0.7^{\mathrm{m}}$ & $1.3 \pm 0.1^{\mathrm{n}}$ & $25.9 \pm 1.3^{\mathrm{e}}$ & $2.6 \pm 0.1^{\mathrm{o}}$ \\
\hline & 1.5 & $10.7 \pm 2.0^{\mathrm{d}}$ & $41.2 \pm 8.2^{\mathrm{h}}$ & $86.3 \pm 3.7^{\mathrm{j}}$ & $35.2 \pm 9.4^{\mathrm{c}, \mathrm{e}, \mathrm{k}}$ \\
\hline & 17.0 & $43.6 \pm 10.9^{\mathrm{h}, \mathrm{k}}$ & $73.7 \pm 22.9^{\mathrm{g}, \mathrm{h}, \mathrm{i}, \mathrm{j}}$ & $169.8 \pm 9.9^{1}$ & $121.1 \pm 2.2^{p}$ \\
\hline
\end{tabular}

687

688 
690 Figure 1. Effect of freeze-drying on viability of lactobacilli. Significant differences $691 \quad(P<0.05)$ are indicated by different letters.

692

693 Figure 2. Adhesion of lactobacilli to Caco-2 cells (CFU adhered per 100 Caco-2 694 cells). Significant differences $(P<0.05)$ are indicated by different letters.

695

696 Figure 3. Adhesion of L. plantarum NCIMB 8826 and L. casei ATCC 393 to $n$ 697 hexadecane. Significant differences $(P<0.05)$ are indicated by different letters.

698

699 Figure 4. SEM micrographs showing: a) the morphology of complete Caco-2 700 monolayer, b) adhesion of free L. casei ATCC 393 bacteria to Caco-2 cells, c) 701 adhesion of L. plantarum NCIMP 8826 bacteria to Caco-2 cells and the level of 702 intercellular junctions (shown by arrows), d) starch granules of wheat interacting with 703 the Caco-2 monolayer and e) immobilized L. casei ATCC 393 cells on wheat grains. 


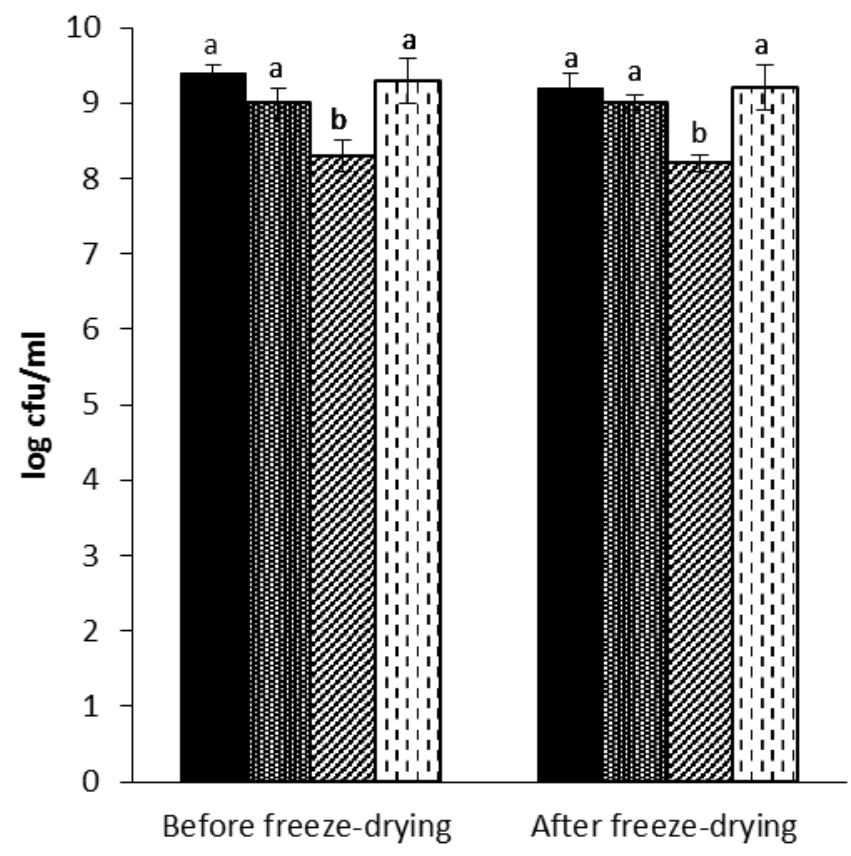

- Free L.plantarum NCIMB 8826

畻 Free L.casei ATCC 393

Immobilized L.plantarum NCIMB 8826

प1 Immobilized L.casei ATCC 393

Fig. 1

707

708

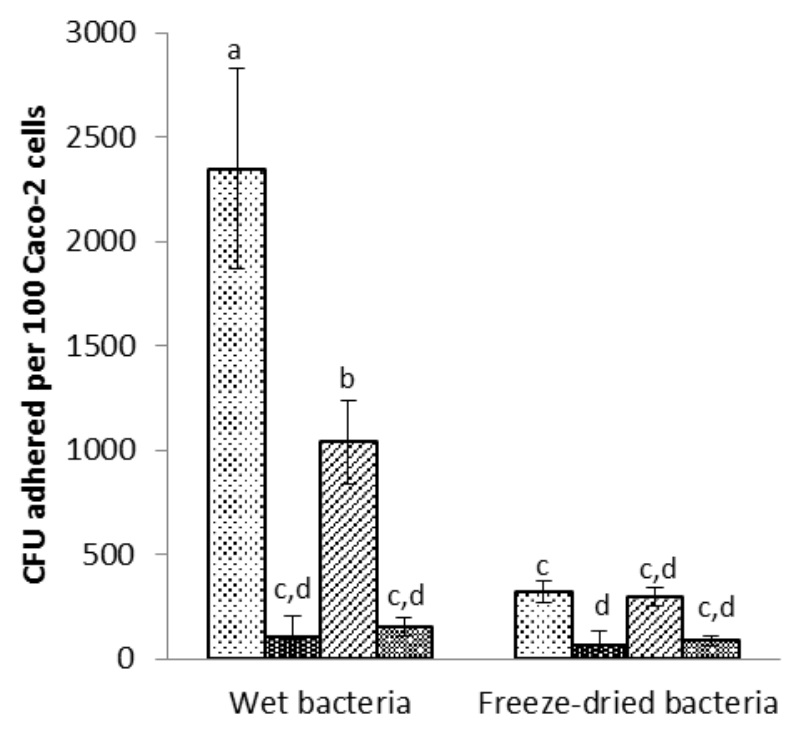

Free L.plantarum

需 Immobilized L.plantarum

ZFree L.casei

Immobilized L.casei

709

Fig. 2

710 
711

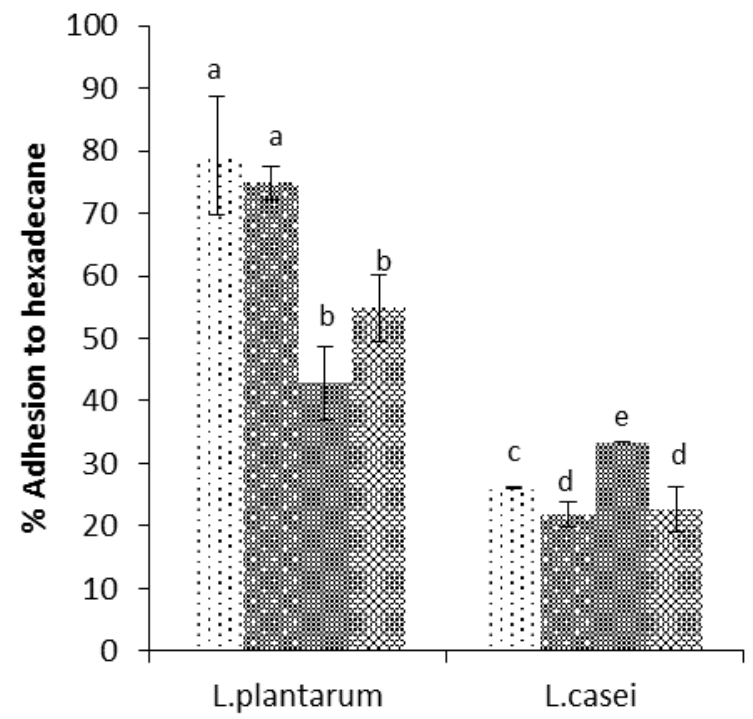

궁 Freeze dried immobilized bacteria

Freeze dried free bacteria

圆 Wet immobilized bacteria

Wet free bacteria

712

Fig. 3.

713 


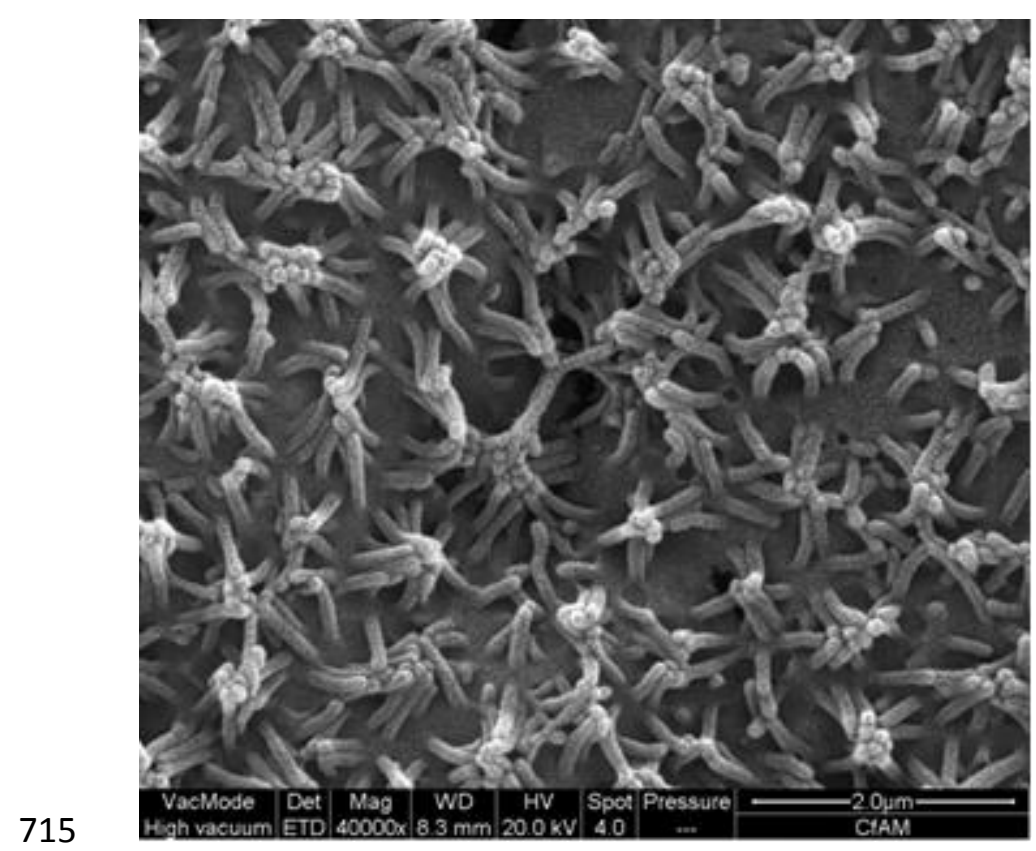

$716 \quad$ Fig. 4a

717

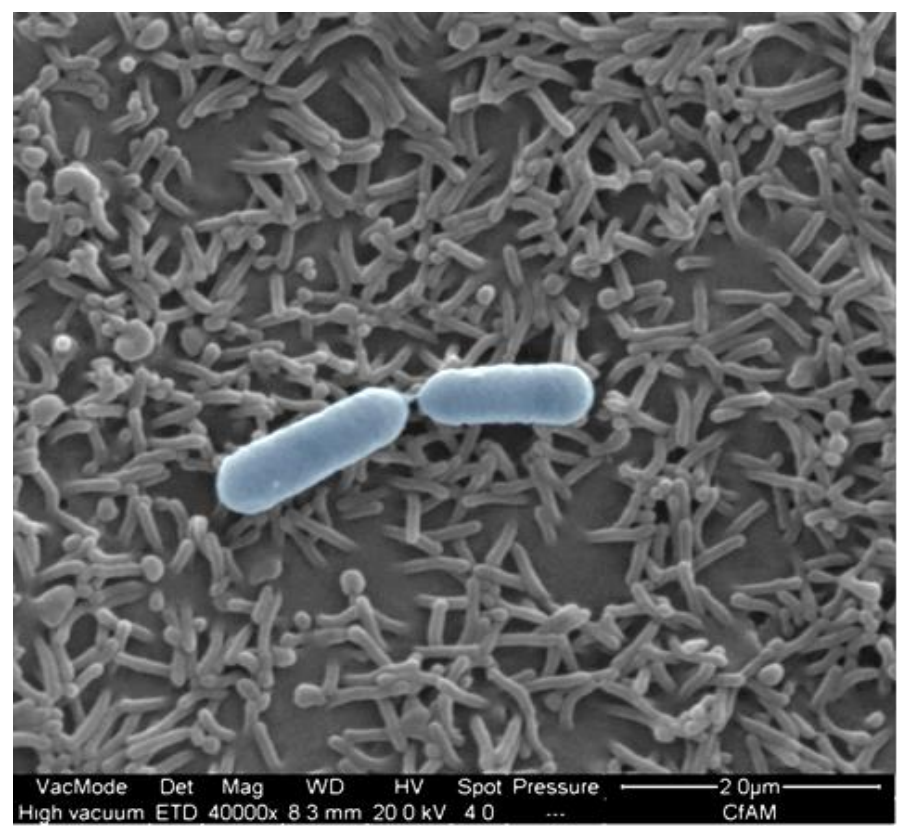

$719 \quad$ Fig. 4b

720

721 


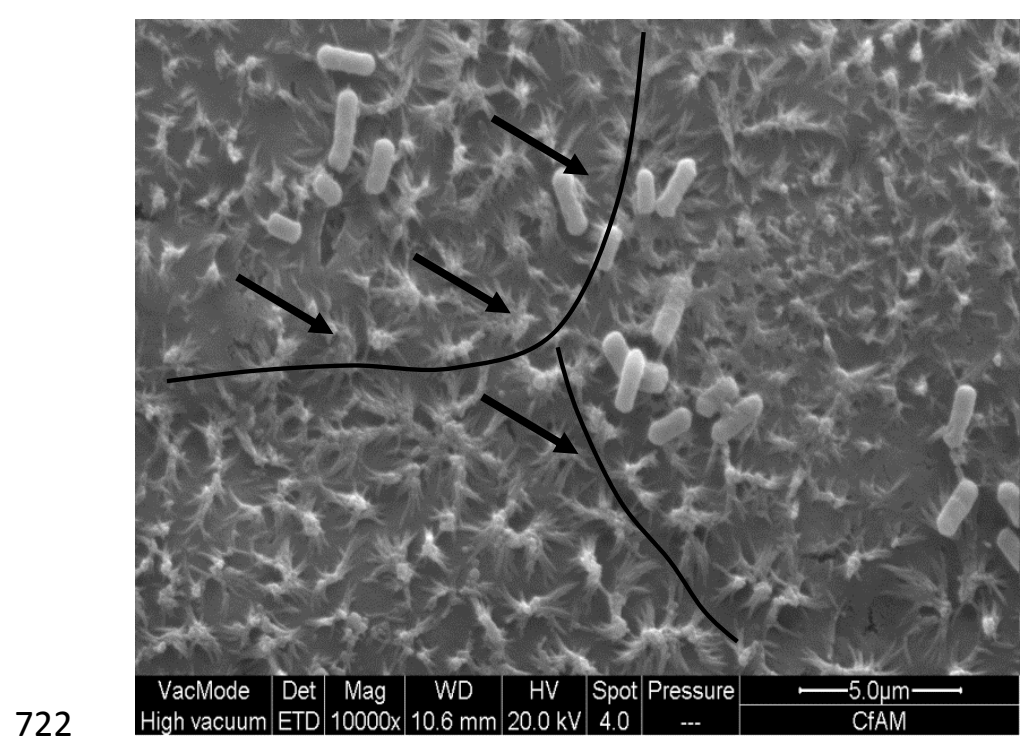

723 Fig. 4c

724

725

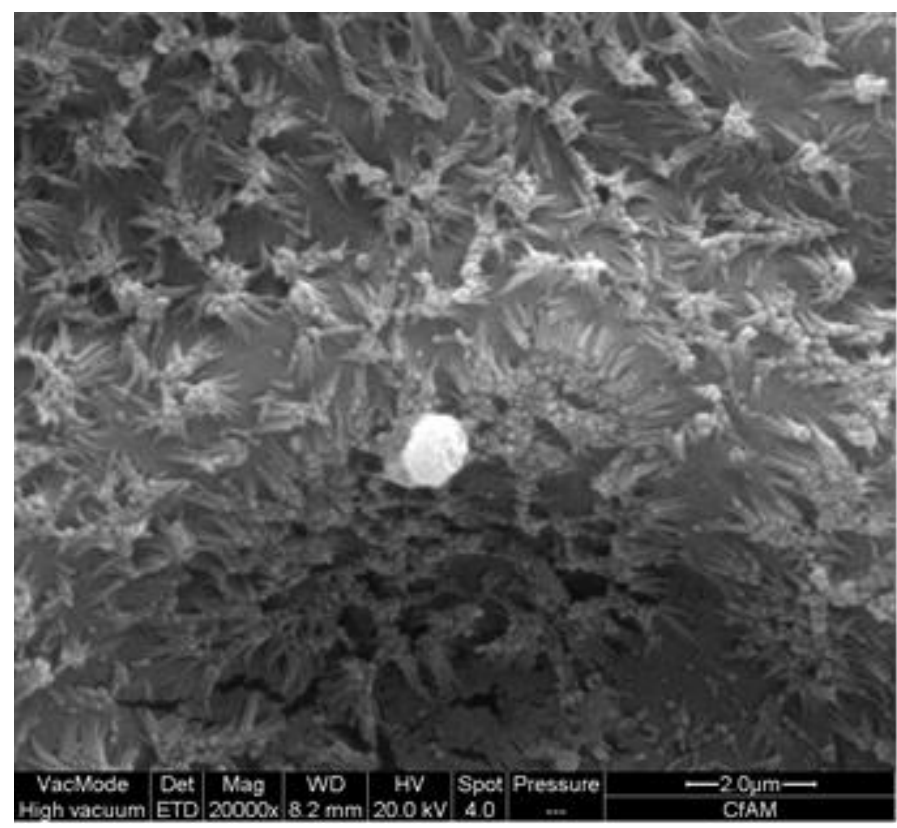

$727 \quad$ Fig. 4d

728 


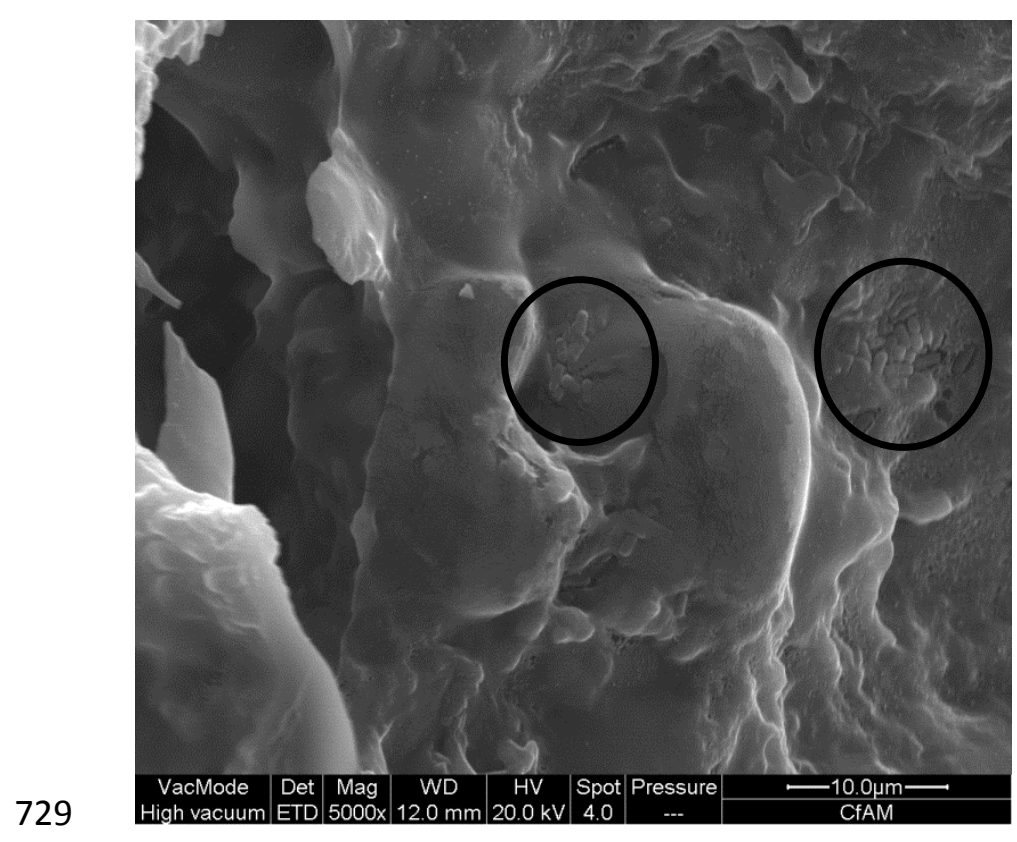

$730 \quad$ Fig. 4e

731

732 